\title{
trabalhonecessário
}

issn: $1808-799 \mathrm{X}$

ano 7 - número 8 - 2009

\section{Empreendedorismo e Educação: o SEBRAE na escola.}

\author{
Graziany Penna Dias' - grandias@ig.com.br
}

\section{Introdução}

O presente texto tem por objetivo tratar criticamente a noção de empreendedorismo e sua apreensão/implementação, a nosso ver, apressada e acrítica, nas ações pedagógicas da educação. Entendemos que esta noção caminha e se relaciona, juntamente, com as outras noções: competência e empregabilidade, que têm sido impostas no seio escolar para atender ao projeto dominante de sociedade, pautada nas mudanças que vêm acontecendo no capitalismo desde o último quartel do século passado $(X X)$.

As discussões que apresentaremos, neste texto, são frutos das pesquisas do mestrado em educação da Universidade Federal Fluminense com o titulo: Empreendedorismo e Educação: o SEBRAE na Escolai" (DIAS, 2006). O objetivo deste estudo foi analisar o empreendedorismo no interior da escola, via SEBRAE, através do seu curso Formação de Jovens Empreendedores, destinado aos alunos do ensino médio.

\section{Reestruturação Produtiva e Formação Humana}

Diversos estudos têm apontado profundas mudanças no mundo do trabalho (ou mercado de trabalho, para as visões apologéticas) que têm indicado transformações na economia política do capitalismo, no último quartel do século $\mathrm{XX}$ e que vem ocorrendo até então (HARVEY, 1993). E essas transformações têm implicado, numa perspectiva de totalidade e mediação, mudanças em outros âmbitos da sociedade, como a cultura e a educação. 


\section{trabalhonecessário}

issn: $1808-799 \mathrm{X}$

ano 7 - número 8 - 2009

A globalização e o neoliberalismo, enquanto grandes processos econômicos e políticos, em curso, que têm promovido mudanças estruturais. Aliada e permeada, por estes, têmos a reestruturação produtiva, que tem impetrado a partir das inovações tecnológicas, mas não só por conta dessas, mudanças no modo de organização da produção, a qual, um novo modelo se apresenta com o nome de toyotismo (GOUNET, 1999).

Isto não implica no desuso dos modelos de organização do passado representados pelo fordismo. O que se observa é uma conjugação de modelos antigos com novos. Neste sentido, a referência de Harvey (1993) sobre a acumulação flexível, e a qual veremos mais à frente, é de fundamental importância para compreender os tempos hodiernos.

No tocante ao fordismo, indicaremos que este representou o principal padrão de acumulação, constituído na grande indústria ao longo do século $X X$, intensivamente a partir da segunda década. Sua data de origem é considerada por volta de 1914 e seu idealizador, Henry Ford, que introduziu a jornada de oito horas e cinco dólares enquanto recompensa aos trabalhadores.

Suas características consistem na produção em massa de mercadorias, baseadas na produção mais homogeneizada e altamente verticalizada, dito de outra forma, a "empresa que faz tudo" (SOUZA, et al., 1999), pois a empresa de inspiração fordista agremiava na sua planta fabril, a maior parte das tarefas da produção de determinada mercadoria. E a realização de tais tarefas eram racionalizadas ao máximo, para diminuir o tempo de produção e o desperdício, e aumentar o ritmo de trabalho. $O$ resultado disto era a intensificação nas formas de exploração (ANTUNES, 2004).

Um outro aspecto era o trabalho parcelar e fragmentado e a decomposição das tarefas que restringiam as ações dos operários 


\section{trabalhonecessário}

issn: $1808-799 \mathrm{X}$

ano 7 - número 8 - 2009

[...] a um conjunto repetitivo de atividades cuja somatória resultava no trabalho coletivo produtor dos veículos. [...] Uma linha rígida de produção articulava os diferentes trabalhos, tecendo vínculos entre as ações individuais das quais a esteira fazia as interligações, dando o ritmo e o tempo necessários para a realização das tarefas. Esse processo produtivo caracterizou-se, portanto, pela mescla da produção em série fordista com o cronômetro taylorista, além de uma separação rígida entre elaboração e execução (ANTUNES, 2004, p. 37).

O termo taylorista se refere ao conjunto de idéias de Frederick W. Taylor, com ênfase na administração científica que ao julgar o trabalhador,

um ser indolente - natural e intencionalmente -, advogava uma radicalização do processo de separação entre gerência, concepção, controle e execução - à gerência cabia o trabalho intelectual; ao trabalhador, o manual -; bem como a decomposição minuciosa do processo de trabalho em movimentos e tarefas fragmentadas e rigidamente controladas pelo tempo, levando em seu bojo a um maior grau de hierarquização e desqualificação no interior do processo de trabalho (SOUZA, 1999, p. 39).

Ford se apropriou de tendências, como o taylorismo, que estavam em curso (desde o século XIX) articulando-as na produção do padrão de acumulação que leva o seu nome. Mas algo de distinto diferenciava Ford e Taylor. De acordo com Harvey.

O que havia de especial em Ford (e que, em última análise distingue 0 fordismo do taylorismo) era sua visão, seu reconhecimento explícito de que produção de massa significava consumo de massa, um novo sistema de reprodução da força de trabalho, uma nova política de controle e gerência do trabalho, uma nova estética e uma nova psicologia, em suma, um novo tipo de sociedade democrática, racionalizada, modernista e populista (HARVEY, 1993, p. 121).

Partindo da obra de Antonio Gramsci, "Americanismo e Fordismo", Harvey disserta que o autor italiano havia chegado à compreensão de que o método de 


\section{trabalhonecessário}

issn: $1808-799 \mathrm{X}$

ano 7 - número 8 - 2009

trabalho de Ford exigia a constituição de um novo tipo de trabalhador e de homem, adequado às novas necessidades impostas pelo seu padrão de acumulação.

Neste sentido, para Ford fazia-se necessário a ação conjunta do Estado, com as políticas keynesianas do bem estar social, além da construção de um mercado consumidor massificado. De acordo com Rodrigues

Para a sustentação e expansão do padrão fordista de produção industrial foi necessária a criação de todo um complexo societário articulado e integrado à produção em massa. Foi necessário reformular-se o papel dos sindicatos, do Estado; foi preciso conformar os corpos, os paladares; foi preciso conformar a escola e a cultura (RODRIGUES, 1997, p. 216).

Em 1970, a crise expressa pelo esgotamento do padrão de acumulação fordista aliado à crise do petróleo contabilizaram mais uma crise estrutural, na qual o mundo capitalista avançado mergulhou numa longa e profunda recessão conjunta à inflação (estagflação) (RODRIGUES, 1997). Neste sentido, o capital precisou realizar um amplo processo de reestruturação, objetivando recuperar o seu ciclo reprodutivo e repor o seu projeto dominante societal (ANTUNES, 1999, p. 47).

A acumulação flexível é um termo proposto por Harvey para destacar as mudanças, ocorridas no capitalismo, no tocante ao aparecimento de um novo padrão de acumulação, apoiado nas inovações tecnológicas, mas não restrito só a elas, e em que a palavra de ordem é a flexibilidade. De acordo com Harvey,

A acumulação flexível, como vou chamá-la, é marcada por um confronto direto com a rigidez do fordismo. Ela se apóia na flexibilidade dos processos de trabalho, dos mercados de trabalho, dos produtos e padrões de consumo. Caracteriza-se pelo surgimento de setores de produção inteiramente novos, novas maneiras de fornecimento de serviços financeiros, novos mercados e, sobretudo, taxas altamente intensificadas de inovação comercial, tecnológica e organizacional. (HARVEY, 1993, p. 140). 


\section{trabalhonecessário}

issn: $1808-799 \mathrm{X}$

ano 7 - número 8 - 2009

Ante a acumulação flexível, uma série de medidas como a precarização do trabalho no que tange aos diretos e remunerações, informalização, flexibilidade nos processos de trabalho tem resultado na crise do emprego formal com acentuado aumento da taxa de desemprego.

Pois, no interior das empresas, com os novos modelos de produção, como o toyotismo, um intenso processo de reestruturação produtiva tem implicado numa série de mudanças, em negação às estruturas rígidas do fordismo, perfazendo a flexibilidade necessária aos novos tempos.

A produção das mercadorias se vincula à demanda do mercado procurando atender às exigências individuais (ANTUNES, 1999). Tomando como exemplo a produção automobilística, o número de carros produzidos é de acordo com os pedidos feitos, o estoque procura ser o mínimo possível, ao contrário do fordismo, que produz em massa para o consumo. Um outro detalhe importante é a variedade de veículos produzidos, ao contrário do fordismo que produzia um modelo em larga escala.

O aparato produtivo toyotista é altamente flexível, adaptando-se às mudanças na produção em curto espaço de tempo (GOUNET, 1999). Nesse esquema as máquinas possuem um funcionamento autônomo na produção; o trabalhador fica encarregado de gerenciar o funcionamento das máquinas e preparar as devidas mudanças nesta, caso a produção se altere. Dessa forma, o trabalhador passa a operar cinco máquinas ou mais ao mesmo tempo. No Fordismo esta relação é de um homem/uma máquina.

O toyotismo possui um sistema denominado de Kan Ban que funciona como placas de registro de peças a serem repostas. Assim quando é necessária uma determinada peça, esta é retirada do estoque com uma pequena placa fixada. Então esta placa é retirada da peça empregada, retornando ao estoque para repor uma nova peça. Isto traduz uma alta versatilidade no interior da empresa, pois desta forma eliminam-se os entraves burocráticos. 


\section{trabalhonecessário}

issn: $1808-799 \mathrm{X}$

ano 7 - número 8 - 2009

Ainda, a estrutura fabril apresenta-se horizontalizada, ou seja, boa parte das funções inerentes à produção é repassada a outras empresas em forma de terceirização, em contrapartida ao fordismo cuja estrutura é verticalizada agremiando praticamente a maioria das funções. Assim, enquanto no fordismo temse $75 \%$ da produção sendo realizada na própria fábrica, na fábrica toyotista apenas $25 \%$ da produção é realizada em seu interior ficando a maior parcela deslocada para outras empresas (ANTUNES, 1999).

No toyotismo os trabalhadores se organizam nos Círculos de Controle de Qualidade (CCQ) onde discutem conjuntamente sobre a elaboração do trabalho, de forma a cada vez mais aumentar a produtividade (ibid.).

Como se pode observar o toyotismo aparece no cenário mundial com características bem distintas do fordismo que até então se apresentava como o modelo ímpar na extração de mais valia, o que não quer dizer que esse último foi substituído pelo toyotismo, pois na visão de Harvey a acumulação flexível também representa um sincretismo das formas de produção de modo em uma fábrica poder se observar lado a lado, métodos antigos e novos.

No tocante ao toyotismo (expressão das fortes mudanças no cenário da acumulação flexível) observamos o processo de terceirização no interior das grandes empresas. Com a horizontalização da organização do trabalho destacada por Swyngedouw (apud. HARVEY, 1993), as grandes empresas passam a não mais realizar todas as tarefas necessárias à produção de suas mercadorias, como era o caso da produção fordista.

O que se tem observado é o processo de terceirização no qual são passadas determinadas tarefas da produção para outras empresas (geralmente micro e pequenas), ficando a grande empresa horizontalizada, por conta da parte principal das tarefas da produção, ou seja, elas agora procuram "focalizar" as tarefas mais rentáveis, deixando o restante para ouras empresas.

Isso, de imediato, proporciona um enxugamento dos postos de trabalho já que as tarefas são reduzidas. Em termos de concorrência de mercado, fica mais lucrativo 


\section{trabalhonecessário}

issn: $1808-799 \mathrm{X}$

ano 7 - número 8 - 2009

pagar a empresas terceirizadas pela realização de determinadas tarefas do que manter um número maior de trabalhadores no interior da empresa que antes realizavam tais tarefas.

De acordo com Singer (2003), estas grandes empresas horizontalizadas optam por comprar serviços das micro e pequenas empresas, em vez de comprar mão-deobra, tal como era feito pela grande empresa verticalizada.

Assim, o processo de terceirização, em especial vem necessitar de uma conjuntura propícia à formação de micro e pequenas empresas que possam assumir as tarefas produtivas compradas pelas grandes empresas horizontalizadas.

Neste sentido, para atender estas novas demandas é necessário um novo tipo de trabalhador que seja educado para as mudanças constantes do mercado de trabalho, na qual a inserção não se opera somente pela via do emprego, mas também pelo "auto-emprego". Por fim, discursos são criados para poder direcionar e convencer os trabalhadores sobre a formação necessária para garantir a sua sobrevivência, sem que se tenha que questionar as relações sociais de produção. $A$ seguir analisaremos estes discursos dispostos sob a aparência de noções de competência, empregabilidade e empreendedorismo.

\section{Noção de Competência, Empregabilidade e EMPREENDEDORISMO.}

No bojo destas transformações, as mudanças de cunho tecnológico e organizacional do trabalho, por que vêm passando os países do capitalismo central (desde meados de 1970) desenham um mundo produtivo com características marcantes.

[...] flexibilização da produção e reestruturação das ocupações; integração de setores da produção; multifuncionalidade e polivalência dos trabalhadores; valorização dos saberes dos trabalhadores não ligados ao trabalho prescrito ou ao conhecimento formalizado. (RAMOS, 2001b, p. 38). 


\section{trabalhonecessário}

issn: $1808-799 \mathrm{X}$

ano 7 - número 8 - 2009

Em que pesem estas características, um novo modelo de trabalhador se faz necessário para compor os novos quadros produtivos em que a formação humana repouse em novas noções que passam a ser balizadoras dos principais espaços de formação, sendo a escola o espaço privilegiado.

Apresentam-se duas novas noções - competência e empregabilidade - no interior do campo da formação humana (RAMOS, 2001a). No que corresponde à competência, esta

[...] associa-se à conjugação dos diversos saberes mobilizados pelo indivíduo (saber, saber-fazer e saber-ser) na realização de uma atividade. Ela faz apelo não somente aos seus conhecimentos formais, mas à toda gama de aprendizagens interiorizadas nas experiências vividas, que constituiriam a sua própria subjetividade. (RAMOS, 2001a, p. 13).

O novo modelo de trabalhador deverá ser preparado não somente através de uma base técnica, mas também com características e habilidades comportamentais tais como criatividade, trabalho em grupo, decisão, resolução de problemas, comunicação entre outras; tornando-se um trabalhador polivalente.

No tocante a institucionalização da noção de competência, Ramos traz importantes considerações, ao verificar que a metodologia de análise dos processos de trabalho tem sido feitas segundo a Teoria Funcionalista, que enquanto aporte metodológico, [...] é coerente com uma concepção natural-funcionalista de conhecimento, que reforçaria o irracionalismo pós-moderno (RAMOS, 2001a, p. 284). De acordo com Ramos, o funcionalismo não se origina nas Ciências Sociais, embora muito divulgado nesta. Ele é oriundo, na verdade, das ciências Biológicas. Neste sentido, essa teoria desconsidera as determinações históricas e contraditórias do objeto de conhecimento, a qual se põe a investigar.

Da mesma forma que na Biologia, o objeto de estudo é o organismo (ou subsistema de um), na Sociologia o objeto é um sistema de ação. Não há lugar para as contradições, mas sim para a interação (RAMOS, 2001a, p. 287). Num sistema, os 


\section{trabalhonecessário}

issn: $1808-799 \mathrm{X}$

ano 7 - número 8 - 2009

elementos sociais realizam funções específicas com um dado propósito, num ambiente de constante equilíbrio. A desarmonia, de tal equilíbrio, seria ocasionada por situações disfuncionais em que se teriam ações subseqüentes para refazer o equilíbrio do sistema.

Já no sistema de base flexível, tal relação se inverte de modo a importar mais à pessoa do que ao papel que exerce. A descrição das funções é realizada em termos de resultados atingíveis por procedimentos dos mais diversos, desde que seja refeito o equilíbrio.

Mas a pessoa que interessa é a pessoa funcional, ou seja, aquela que mobiliza seus atributos cognitivos e sócio-afetivos para obter resultados esperados. Então, na verdade, a unidade mínima da análise funcional desloca-se do posto de trabalho para a competência dos trabalhadores. (RAMOS, 2001a, p. 288).

Não obstante, a mudança de enfoque, necessita também da mudança de compreensão da organização do sistema, que passa agora a ser compreendido, como sendo aberto. E a personalidade e as relações interpessoais apresentam-se muito necessárias ao processo.

Por isso, os atributos psicológicos dos indivíduos tomam importância para o funcionamento integrado e flexível das organizações. Ao mesmo tempo, que o que se considerava como disfunções no funcionalismo clássico, será chamado agora de eventos e, ao invés de serem considerados indesejáveis ou anormais, passarão a compor o funcionamento dos sistemas. (RAMOS, 2001a, p. 288).

Este aprimoramento da Teoria Funcionalista é realizado pela Teoria Geral dos Sistemas, adaptando o funcionalismo a realidade econômico-produtiva hodierna. Nesta concepção, a matriz construtivista advém para analisar os, agora, eventos.

A análise construtivista, de aparência inovadora, ancora-se no mesmo constructo teórico, conferindo, porém, relevância ao 


\section{trabalhonecessário}

issn: $1808-799 \mathrm{X}$

ano 7 - número 8 - 2009

elemento do sistema antes subordinado ao funcionamento normal; os eventos. Como unidade de análise dessas metodologias, a competência configura-se como uma noção adaptadora do comportamento humano à realidade contemporânea. (RAMOS, 2001a, p. 289).

Aliás, a adaptação é uma categoria fundamental da concepção funcionalnaturalista de homem, na qual a socialização viria da interação e adaptação ao meio físico e social, visando o equilíbrio com estes.

No modelo biológico de interação organismo-meio estão presentes as noções de adaptação e equilíbrio. As características internas ao indivíduo seriam mediadoras na relação entre o organismo vivo e a espécie a que pertence. $\mathrm{O}$ amadurecimento dessas características internas permitiria que os indivíduos se desenvolvessem segundo uma seqüência fixa e universal de estágios, tal como postulou Piaget. (RAMOS, 2001a, p. 290).

O desenvolvimento psicológico do ser humano consistiria ao desenvolvimento de mecanismos de adaptação aos meios material e social. Assim, as competências cognitivas abarcariam os mecanismos de adaptação ao meio material ou mundo das coisas; e as competências sócio-afetivas abarcariam os mecanismos de adaptação ao meio social ou mundo das pessoas (RAMOS, 2001a, p. 290).

O homem naturalista da Biologia e da Psicologia é o homem

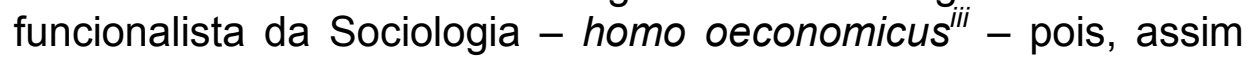
concebido, o indivíduo agiria na sociedade de acordo com suas determinações naturalmente dadas contribuindo para o equilíbrio social. (RAMOS, 2001a, p. 290, grifos nossos).

Neste sentido, a perspectiva das competências consistiria numa adaptação do indivíduo a sociedade sem perspectiva de transformação.

A competência, inicialmente tomada como fator econômico e aspecto de diferenciação individual, reverte-se em benefício do 


\section{trabalhonecessário}

issn: $1808-799 \mathrm{X}$

ano 7 - número 8 - 2009

consenso social, envolvendo todos os trabalhadores supostamente numa única classe: a capitalista, ao mesmo tempo, forma-se um consenso em torno do capitalismo como o único modo de produção capaz de manter o equilíbrio e a justiça social. (ibid., p. 291).

Sendo assim, Ramos conclui que a noção de competência situa-se num plano de em que convergem a Teoria Interacionista da formação do indivíduo e a Teoria Funcionalista da estrutura social. Esta primeira [...] demonstra que sob uma determinada concepção de homem - a naturalista - a competência torna-se característica psicológico-subjetiva de adaptação do trabalhador à vida contemporânea (RAMOS, 2001a, p. 292). A segunda, [...] situa a competência como fator de consenso à manutenção do equilíbrio da estrutura social, à medida que o funcionamento desta última ocorre muito mais por seqüência de eventos do que por seqüência de fatos previsíveis (RAMOS, 2001a, p. 292).

Assim, Ramos qualifica a noção de competência, enquanto perfazendo uma concepção natural-funcionalista de homem, que desemboca numa concepção subjetivo-relativista de conhecimento, isto, posto que o processo de construção de conhecimento pelo indivíduo representaria o próprio processo adaptativo ao meio material e social. Nesta compreensão, a busca do conhecimento não adviria de um [...] esforço de compreensão da realidade para, então, transformá-la, mas sim das percepções e concepções subjetivas que os indivíduos extraem do seu mundo experiencial (ibid., p. 292).

No que tange a empregabilidade, tal noção caminha junto com a noção de competência, correspondendo, ideologicamente, à condição do trabalhador se tornar empregável num momento em que flexibilizam-se as relações e condições de trabalho.

A empregabilidade representaria a contínua preparação que o trabalhador deveria buscar para se manter no emprego ou, se o perder, conquistar um outro emprego pela via da sua capacitação. De acordo com Minarelli (1995) a palavra empregabilidade é equivalente à expressão norte americana employability que se 


\section{trabalhonecessário}

issn: $1808-799 \mathrm{X}$

ano 7 - número 8 - 2009

refere à "habilidade de ter emprego" (MINARELLI, 1995, p. 37). Atendendo aos ajustamentos da economia global, as empresas modificam-se velozmente não garantindo mais o emprego até o trabalhador se aposentar. Inclusive, segundo Minarelli (ibid.), são cada vez mais raras as carreiras feitas apenas em uma única empresa.

Entretanto, mais do que uma expressão, a empregabilidade opera como mecanismo ideológico que adentra na realidade como forma de justificar as contradições da sociedade capitalista. De acordo com Ramon de Oliveira (1999), procura-se, pôr fora de questão, as relações de classe, enquanto responsáveis pela crise hodierna.

O conceito de empregabilidade surge, neste ínterim, como um mecanismo que retira do capital e do Estado a responsabilidade pela implementação de medidas capazes de garantir um mínimo de condições de sobrevivência para a população. Ao se responsabilizar os indivíduos pelo estabelecimento de estratégias capazes de inseri-los no mercado de trabalho, justifica-se o desemprego pela falta de preparação dos mesmos para acompanharem as mudanças existentes no mundo do trabalho. Sob a ótica da empregabilidade, a necessidade dos indivíduos disporem de habilidades e conhecimentos adequados aos interesses da produção passa a ser o primeiro elemento considerado nas discussões a respeito das possibilidades de superação do desemprego existente. (OLIVEIRA, 1999, p. 57).

Em matéria no jornal Tribuna de Minas a noção de empregabilidade é destacada enquanto sendo a solução para a crise do emprego na cidade. Sob o título JF [Juiz de Fora] perde 200 postos por falta de mão-de-obra qualificada a matéria destaca que na verdade não há falta de emprego, mas de qualificação. Devido ao chamado "vácuo de empregabilidade" a cidade tem perdido empregos devido a não instalação de indústrias na região (TRIBUNA DE MINAS, 2005).

De nossa parte, acrescentamos a noção de empreendedorismo que tem ganhado o espaço no discurso dominante com forte apelo ao "auto-emprego", de 


\section{trabalhonecessário}

issn: $1808-799 \mathrm{X}$

ano 7 - número 8 - 2009

modo à pessoa tornar "patrão de si mesmo", haja vista as altas taxas de desemprego e subemprego.

A noção empreendedorismo que também recebe a denominação de empreendedorismo schumpeteriano é derivada dos estudos do economista liberal Joseph A. Schumpeter, que, nos seus estudos sobre o desenvolvimento econômico do capitalismo, identificou como fenômeno fundamental à figura do empreendedor.

De acordo com Pombo (2005), Schumpeter destaca que o sistema capitalista tem como característica inerente, uma determinada força que ele denominou, em seu livro Capitalismo, Socialismo e Democracia (publicado em 1942), de "processo de destruição criativa" na qual o desenvolvimento de novos produtos, novos métodos de produção e novos mercados; perfaz a destruição do velho pelo novo. $E$ o agente central neste processo de destruição criativa seria a figura do empreendedor. Em 1911, a publicação do seu livro Teoria do Desenvolvimento Econômico (1961b), deu um enfoque destacado ao empreendedor. Para Schumpeter, o empreendedor é aquele que cria inovações que possibilitam obter lucro com assunção dos riscos. "Ao empreendimento de novas combinações denominamos 'empresa' e os indivíduos, cuja função é realizá-las, 'empreendedores'” (SCHUMPETER, 1961a, p. 103).

Schumpeter, também fez a diferenciação do empreendedor e do dono da empresa a qual nem sempre há correspondência.

[...] chamamos empreendedores não só aqueles homens de negócios "independentes", de uma economia mercantil [...] como também todos os que, realmente preenchem, aquela função que definimos; ainda que, como está sendo a regra, sejam empregados "dependentes" de uma companhia [...] por outro lado, o nosso conceito é mais restrito que o tradicional, pelo fato de não abranger todos os diretores de firmas, gerentes ou industriais que, simplesmente, apenas dirigem um negócio estabelecido [...]. (SCHUMPETER, 1961a, p. 103-104). 


\section{trabalhonecessário}

issn: $1808-799 \mathrm{X}$

ano 7 - número 8 - 2009

Em outro momento, Schumpeter destaca a provisoriedade do empreendedor, de modo a este não permanecer "eterno": "[...] alguém só é um empreendedor, quando realmente, empreende novas combinações e perde esta característica logo que estabelece negócios, quando os estabiliza, deixando-os correr, como outras pessoas" (SCHUMPETER, 1961a, p. 102).

Neste sentido, ser empreendedor não é uma profissão e muito menos uma condição duradoura. Eles, os empreendedores, não constituiriam uma classe, "[...] como, por exemplo, os latifundiários, ou capitalistas, ou operários" (SCHUMPETER, 1961a, p. 108), ainda que com seus esforços consigam ascender a alguma.

Para Schumpeter, a capacidade de inovação seria um atributo fundamental ao empreendedor de modo a este procurar dar originalidade aos negócios, pois, do contrário, ao cair em ações rotineiras, suas atividades não poderiam mais ser consideradas empreendedoras.

Num outro esforço teórico de desenhar a figura do empreendedor, para Schumpeter, este estaria para além dos desejos e desígnios materiais.

Há a vontade de conquistar: o ímpeto de lutar, de provar-se superior aos outros, de vencer, não pelos frutos da vitória, mas pela própria vitória. Sob esse aspecto, a ação econômica se assemelha ao esporte - há corridas financeiras, idênticas a partidas de boxe. O resultado financeiro é uma consideração secundária, em todo caso, porém, muito valorizado como índice de sucesso e como sintoma de vitória [...]. (SCHUMPETER, 1961a, p. 128).

O empreendedor, segundo Schumpeter, poderia ser comparado como uma espécie de jogador que joga pelo prazer de jogar e em que os ganhos materiais são como troféus que demonstram sua superioridade. Aqui observamos uma percepção bem idealista de homem, que está para além das determinações materiais. Inclusive Schumpeter chega diferir o seu empreendedor da visão de homo oeconomicus, pois este seria capaz de recuar perante os empreendimentos de alto risco ao perquirir 


\section{trabalhonecessário}

issn: $1808-799 \mathrm{X}$

ano 7 - número 8 - 2009

somente o lucro nas suas atividades econômicas; já o empreendedor vai para além do lucro, visando mais à satisfação da vitória.

Em linhas gerais, a exposição feita até o momento procurou destacar a figura do empreendedor concebida por Schumpeter. No tocante ao empreendedorismo, expressão não citada por Schumpeter, mas implícita na usa obra, representa um neologismo da sua noção de empreendedor e serve para designar as inovações geradoras de desenvolvimento econômico.

Em recente matéria, na Revista EXAME, com o título "Inovação e Empreendedorismo", a inovação é posta como pedra de toque do crescimento e desenvolvimento das empresas. Não bastaria só investir em laboratórios de pesquisa e desenvolvimento para obter crescimento e lucratividade. Tomando como exemplo a empresa japonesa Toyota, a matéria procurou enfatizar o estímulo ao empreendedorismo de seus funcionários, tornando-se a maior empresa do mundo, no faturamento, em fevereiro deste ano. E qual seria seu "segredo". De acordo com a matéria:

Embora apontada como referência na indústria automobilística, a Toyota tem investimentos em pesquisa e desenvolvimento inferiores aos das rivais [General Motors, Ford e Daimler Chrisler]. Seu trunfo é outro - a extraordinária capacidade de mobilizar e estimular seus operários a exercitar o cérebro, em vez de apenas músculos. (Revista EXAME, 2006, p. 02).

O incentivo ao empreendedorismo já faz parte da filosofia da empresa. Nas palavras do consultor canadense Gifford Pinchot: "A inovação desde sempre pressupôs a capacidade de empreender dos funcionários. Sem esse ingrediente, ela simplesmente não acontece" (Revista EXAME, 2006, p. 02). Pinchott, inclusive chega a cunhar uma nova expressão, para este fato: a de intra-empreendedorismo, para designar os trabalhadores da empresa que representam agentes inovadores. $E$ para tal, as empresas devem estimular seus funcionários a ir além da função específica do cargo que ocupam. Assim a noção de empreendedorismo vai se dinamizando em outras expressões de forma a atender a instabilidade do mercado. 


\section{trabalhonecessário}

issn: $1808-799 \mathrm{X}$

ano 7 - número 8 - 2009

De acordo com Campos

A expressão torna-se de domínio público, empregada atualmente em associação com a idéia de um conjunto de competências, geralmente variáveis segundo o contexto, que compõem o perfil do ator, adequado às transformações sócio-econômicas que seguem seu curso a partir da década de 70 [século XX]. (2003, p. 89).

Como veremos mais adiante, as noções de competência, empregabilidade e empreendedorismo; guardam relação entre si enquanto mecanismos ideológicos de convencimento da classe trabalhadora.

\section{Diagrama que relaciona as noções de competência, empregabilidade e} empreendedorismo Fonte (DIAS, 2006, p. 47).

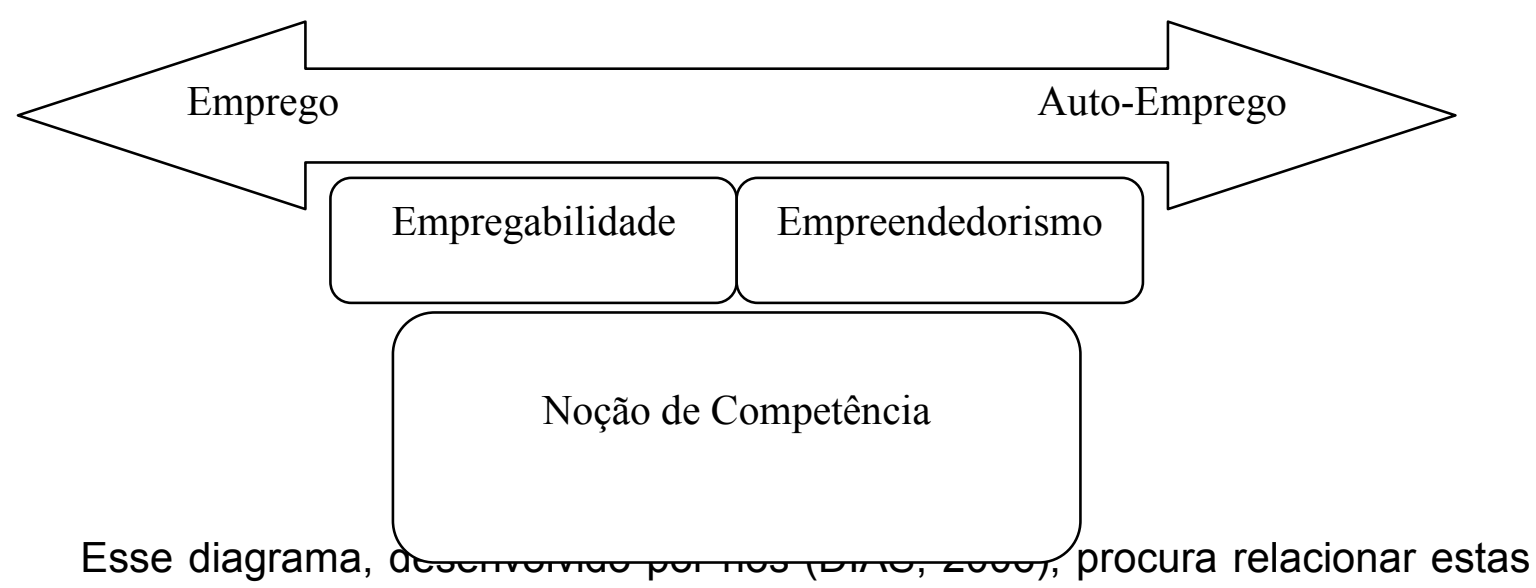

três noções, no que tange ao discurso dominante endereçado à classe trabalhadora para o enfrentamento da crise do desemprego estrutural.

De acordo com este diagrama, as noções de empregabilidade e empreendedorismo têm como base a noção de competência que lhes dá sustento. A noção de empregabilidade reporta que com as devidas competências adquiridas pela constante capacitação, o indivíduo pode conquistar a sua inserção no mercado via emprego. De acordo com Ramos (2001b), a partir de um conjunto de competências o indivíduo pode se tornar empregável, ou seja, adquirir alguma vaga ou emprego em que sua qualificação atender ao mercado. 


\section{trabalhonecessário}

issn: $1808-799 \mathrm{X}$

ano 7 - número 8 - 2009

Já a noção de empreendedorismo assevera que com as devidas competências, a pessoa é capaz de criar o "auto-emprego", tornando-se "patrão de si mesmo". A noção de empreendedorismo enfatiza que o indivíduo construa a sua "atividade remunerativa", já que o número de vagas de emprego, segundo o discurso dominante, está gradativamente diminuindo por conta das mudanças tecnológicas. Assim, a empregabilidade apontaria mais para o emprego e o empreendedorismo apontaria mais para o "auto-emprego". E a noção de competência seria a base e a referência para ambas.

No âmbito educacional, enquanto importante espaço de formação humana, essas noções têm ganhado terreno por meio de programas, projetos, cursos. E também por diferentes personagens que têm atuado junto à educação com o intuito de implementá-las. No caso do empreendedorismo, estamos nos referindo ao SEBRAE que têm cursos organizados para formar, ou conformar, o novo modelo de trabalhador auto-empregado. Entretanto, antes de adentrarmos nos cursos oferecidos pelo SEBRAE, compreendemos que se torna importante entender as suas linhas de deferências no que se refere ao empreendedorismo. A seguir trataremos da constituição histórica do SEBRAE e sua apropriação dessa noção em suas ações.

\section{SEBRAE e o Renascimento da Fênix ${ }^{\text {iv }}$}

A constituição da história do SEBRAE (Sistema Brasileiro de Apoio às Micro e Pequenas Empresas) é caudatária das mudanças ocorridas na década de 1990, mas que se inicia no período de 1960-70, quando se tem a criação do CEBRAE (Centro de Brasileiro Assistência Gerencial à Pequena e Média Empresa), enquanto Centro Brasileiro de Assistência Gerencial à Pequena e Média Empresa, o SEBRAE com "C", com o intuito de atender às demandas dominantes da época. 


\section{trabalhonecessário}

issn: $1808-799 \mathrm{X}$

ano 7 - número 8 - 2009

Em 1990, o Brasil passa a ser governado pelo presidente Fernando Collor de Mello que promove a abertura comercial por meio da extinção de barreiras nãotarifárias e das alíquotas de importação (BOITO JR., 1999). Isto representou um forte impacto na atividade econômica e nas empresas. As empresas nacionais que até então estavam protegidas em seu próprio mercado, tiveram de fazer ajustes impostos pelo processo de abertura, já que o Estado não seria mais o grande interventor na esfera econômica, abrindo espaços para a atuação do mercado.

Em março de 1990, que representa o início do governo Collor, foi editada a Medida Provisória 151 que promoveu a desvinculação de vários órgãos do governo. $E$ entre eles está o CEBRAE. Isto praticamente significava a extinção do Sistema CEBRAE que dependia de recursos do orçamento.

Frente a esta situação, que ainda não estava fechada, pois dependia do aval do Congresso Nacional, mas que já caminhava, pois os funcionários do órgão já estavam com os salários atrasados em três meses. Isto gerou toda uma mobilização junto aos empresários do segmento, com realização de manifestações públicas para a revogação da medida pelos deputados que se viram pressionados.

O CEBRAE enquanto uma força social importante ao segmento do pequeno empresariado tinha uma inserção capilar importante, o que Ihe valeu uma defesa política considerável frente ao Executivo. A primeira tentativa do Executivo em acabar com o Sistema CEBRAE foi ao governo Sarney, que falhou pelo veto do Legislativo (SEBRAE, 2002).

A segunda tentativa, com o governo Collor, também se verá às voltas com o fracasso, pois ao invés de desaparecer, o CEBRAE irá renascer com maior força. Nas palavras do presidente Flávio Ramos, sobre aquele momento de sua gestão.

É interessante observar que a força da Casa vem daquela época. Com toda essa adversidade, sem salário, o corpo funcional se uniu, fechando a questão em defesa do CEBRAE. E lutou para mudar esse quadro. E assim foi que, através da Lei 8.029, ao invés de simplesmente desaparecer, o CEBRAE foi desvinculado 


\section{trabalhonecessário}

issn: $1808-799 \mathrm{X}$

ano 7 - número 8 - 2009

da administração pública e transformado em serviço social autônomo. (SEBRAE, 2002, p. 94).

A fala, de um dos funcionários que lutou pela preservação da instituição, também ilustra bem a conjugação de esforços daquele momento.

Houve, sim, um trabalho muitíssimo bem articulado da Associação dos Funcionários. Foi uma coisa estrategicamente definida, quase uma operação de guerra. Nós avaliávamos tudo, detalhe por detalhe. Aqueles momentos marcantes, pois a dificuldade acaba unindo. Acreditávamos naquilo que estávamos fazendo. Alguns já vinham trabalhando desde o início do Sistema. Fizemos um lobby muito simpático, porque tínhamos resultados a apresentar. Foi muito gratificante observar que deputados e senadores reconheciam a importância do trabalho do CEBRAE local, em seu Estado. A realidade mostra que estávamos certos. Pois, agora, todas as instituições voltam seus olhos para as pequenas empresas. Nós sempre tivemos uma visão de futuro. Então, se a gente fizer uma boa leitura agora, nesse momento, nós também podemos acertar pelos próximos 20 anos. (SEBRAE, 2002, p. 94).

Assim, em maio de 1990, a MP 151 é revertida no Congresso Nacional. Dá-se, nas palavras do próprio SEBRAE, "a grande virada". Em 09 de outubro do mesmo ano, o Decreto 99.570 muda a denominação do CEBRAE para SEBRAE - Serviço Brasileiro de Apoio às Micro e Pequenas Empresas.

A Lei 8.029, além de transformar o SEBRAE em serviço autônomo, também determina recursos para a nova entidade, autorizando o acréscimo em três décimos por cento das contribuições, calculadas sobre a folha de salários das empresas e destinadas ao SENAI, SENAC, SESI e SESC ${ }^{\vee}$. Pode-se dizer que foi o primeiro amparo legalmente registrado de fonte mantenedora do Sistema SEBRAE (exCEBRAE).

Nos anos que se seguiram, na primeira metade da década de 1990, a sua atuação pautou-se pela interiorarização de atendimentos nas seguintes áreas: tecnologia, consultoria e treinamento, mercado, pesquisas, mercado internacional e informação (SEBRAE, 2002). Distribuíram-se pelos 27 estados brasileiros uma 


\section{trabalhonecessário}

issn: $1808-799 \mathrm{X}$

ano 7 - número 8 - 2009

extensa rede de "Balcões" para a difusão de informações e leia-se também a difusão da "nova" instituição.

Em 1995, o empreendedorismo é focalizado no centro das atenções e ações do SEBRAE. Por meio de publicações da "Série Idéias e Propostas" o SEBRAE expõe as diretrizes de adaptação e a apresentação de planos e metas para o qüinqüênio 1995-2000 assentados sobre uma nova interpretação do processo de crescimento econômico e do papel do Estado (CAMPOS, 2003, p. 135).

De acordo com o SEBRAE, no novo enfoque às micro e pequenas empresas (MPE) passam a não serem apenas coadjuvantes do processo de desenvolvimento brasileiro como se apregoava correntemente nas décadas de 1970-80. Agora, ainda que de forma ideológica, as MPE representam os protagonistas deste processo. Aliás, a expressão protagonismo será utilizada, repetidas vezes, no discurso da entidade. Nas palavras do ex-presidente do SEBRAE, Sérgio Moreira (1999-2003).

A pequena empresa é a solução para duas das principais macropropriedades do País. A primeira é o combate à exclusão social. $O$ que não se alcança apenas com políticas sociais compensatórias. Tais políticas permitem uma renda mínima, a sobrevivência das pessoas, mas não são políticas libertadoras. A libertação se dá através da autonomia, do trabalho, do negócio, de algo que faça com que as pessoas tenham renda. E, a partir da renda, da ocupação, do trabalho, se gera a libertação. Os pequenos negócios são os únicos hoje que geram empregos, oportunidades e renda. É um dado da realidade. Nos últimos sete anos, as pequenas e microempresas foram responsáveis pela geração de $96 \%$ de todo o emprego criado no Brasil. As grandes e médias empresas contribuíram tão somente com $4 \%$. Em segundo lugar, as exportações. O modelo de exportação brasileiro esgotou-se. Cumpriu seu papel, de maneira até vitoriosa, mas não consegue se multiplicar. Porque foi montado na base de políticas e incentivos voltados para grandes empresas, grandes negócios. O contrário disso aconteceu na Espanha e na Itália, nos últimos 30 anos, a ponto de as pequenas empresas serem responsáveis hoje por mais de $50 \%$ das exportações desses países. (SEBRAE, 2002, p. 146). 


\section{trabalhonecessário}

issn: $1808-799 \mathrm{X}$

ano 7 - número 8 - 2009

Numa perspectiva histórica, tal raciocínio é bem estratégico ante as transformações decorrentes da conjuntura internacional, que impõe novas demandas em nível macro, para as nações, e micro, para os indivíduos, e ambos numa perspectiva de competitividade. Assim, o discurso do empreendedorismo aparece estrategicamente num momento oportuno em que se observa um ambiente propício ante as altas taxas de desemprego, que seriam inevitáveis, na visão do SEBRAE, por causa da globalização e seus efeitos no mercado de trabalho. Nos estudos, feitos pelo SEBRAE, sobre a realidade do emprego.

As pessoas são fortemente influenciadas, em algum momento do ciclo da vida, pela idéia de conquistar um emprego seguro. Alguns, nas décadas de sessenta e setenta almejavam trabalhar em uma grande empresa, seja estatal, privada ou multinacional [...]. No Brasil e em outros países do mundo, a partir do início da década de oitenta, esta realidade começou a mudar radicalmente, quando o avanço científico e tecnológico fez surgirem novas tecnologias, que passaram a ser utilizadas pelas grandes empresas com intensidade. A automação dos escritórios e dos processos produtivos nas fábricas começaram a eliminar empregos antes oferecidos. Em paralelo, o surgimento e a adoção de novos modelos gerenciais deram ensejo a novas práticas de administração nas empresas, como a de "enxugamento de estruturas" e contribuíram para a eliminação de postos de trabalho na hierarquia das empresas, reduzindo a oferta de empregos antes existentes. (SEBRAE, 1995b, p. 23).

E, acrescenta, com relação à segurança no emprego.

O acirramento da competição entre empresas faz com que elas estejam continuamente revendo sua dimensão, seus produtos e processos operacionais, criando instabilidade na força de trabalho. A oferta de novos postos de emprego passou a ser mais escassa e o emprego existente já não é tão mais seguro para o seu ocupante. Apesar da mudança conjuntural, a crença construída durante anos, de que um bom emprego garante uma vida mais confortável e segura para o seu ocupante, ainda permanece. (SEBRAE, 1995b, p. 23). 


\title{
trabalhonecessário
}

issn: $1808-799 \mathrm{X}$

ano 7 - número 8 - 2009

Na compreensão do SEBRAE, os desafios e as perspectivas postas pelo novo contexto mundial põem em cheque a tese (de décadas atrás) sobre o emprego e a sua seguridade. Apologeticamente, o SEBRAE anuncia que o mundo caminha para a escassez de empregos, colocando, ao mesmo tempo, em marcha um único caminho de sobrevivência: a busca pelo "auto-emprego".

\begin{abstract}
Se, por um lado, pode-se questionar quais as perspectivas de uma nova empresa, criada neste contexto da economia globalizada, por outro é preciso enfrentar a escassez de empregos promissores e seguros. Assim, a tendência é de que cada vez mais pessoas tenham que gerar suas próprias oportunidades de trabalho. Estamos vivendo a nova era do autoemprego e, por ser pioneiro e precursor, o empreendedor que nela está ingressando já parte com vantagens. (SEBRAE, 1995b, p. 26).
\end{abstract}

Neste sentido, tornar-se empreendedor seria estar na vanguarda das formas e estratégias de sobrevivência e enriquecimento. Da mesma forma, quem liderar e operacionalizar esse processo, será o depositário do status de importância que o tema enseja na sociedade.

Não obstante, o SEBRAE associa o seu momento histórico de renascimento ao novo enfoque dado às MPE, pois vislumbra-se um crescimento vertiginoso desse segmento, ante aos processos de parcerias entre empresas de grande porte com as de pequeno porte, a partir dos processos de terceirização (SEBRAE, 1995b).

Assim sendo, o empreendedorismo entra no centro de atenções e ações do SEBRAE, procurando equalizar seu discurso com as transformações no cenário mundial, procurando dar respostas à instabilidade do mercado enquanto o grande proferidor da ordem de funcionamento da economia.

Nessa perspectiva, podemos falar num modelo de empreendedorismo que aqui vamos denominar de schumpeteriano/cooperativo e tende a ser a tônica da formação da cultura empreendedora, via SEBRAE, em face do contexto histórico, determinado pelas mudanças ocorridas no capitalismo nas últimas décadas. 


\section{trabalhonecessário}

issn: $1808-799 \mathrm{X}$

ano 7 - número 8 - 2009

Atualmente, o SEBRAE está sob a direção do diretor-presidente Paulo Okamotto, que representa a continuidade da gestão anterior no que concede ao enfoque do empreendedorismo e da luta por condições favoráveis para as MPE.

Em entrevista concedida a revista Vencer ${ }^{\mathrm{vi}}$, Okamotto destaca o crescimento do empreendedorismo nos últimos anos. Através de pesquisas feitas pelo Instituto Brasileiro de Produtividade e Qualidade (IBPQ), localizado no Paraná, por meio de metodologia da

A chamada TEA, a taxa de Atividade Empreendedora Global, o percentual da População Economicamente Ativa que está empreendendo, tem girado em torno de $13 \%$ - bem alto. Em números absolutos, estima-se que existam 15 milhões de empreendedores no Brasil, contingente que, em 2004, só perde para os Estados Unidos. (REVISTA VENCER, 2005, p. 70).

Do resultado apresentado, estima-se que o crescimento do empreendedorismo se satisfaz no setor de serviços.

O setor de serviços é o que concentra maior quantidade de empreendedores. É o comércio varejista, restaurante, bar, pousada, áreas de educação e lazer, por exemplo. No Brasil, assim como nos outros países de baixa renda per capita pesquisados, isso é explicável, de acordo com o levantamento GEM em inglês -, em parte porque os negócios criados estão vinculados a setores tradicionais, de baixíssimo teor de inovação e que exigem investimento inicial não muito elevado. (REVISTA VENCER, 2005, p. 70).

Mas as realidades de cada país podem oferecer ambientes favoráveis ou não ao desenvolvimento do empreendedorismo. No caso do Brasil, Okamotto destaca que "empreender é um ato de heroísmo" (ibid.), pois o ambiente é perverso para as MPE. Há um excesso de burocracia e de impostos, além da falta de acesso aos recursos financeiros, mercados e grande defasagem tecnológica. 


\section{trabalhonecessário}

issn: $1808-799 \mathrm{X}$

ano 7 - número 8 - 2009

Mas soluções para reverter tal ambiente, já estão a caminho. De acordo com Okamotto, a principal solução refere-se.

[...] à Lei Geral das Micro e Pequenas Empresas, organizada pelo Sebrae. Trata-se de uma lei complementar prevista no capítulo da reforma tributária da Constituição que dá tratamento favorecido, diferenciado e simplificado ao segmento. É ainda um anteprojeto, mas tem condições de vir a ser aprovada este ano pelo Congresso Nacional. Será o marco regulatório das MPE's, as micro e pequenas empresas. Com medidas inovadoras, especialmente contra a burocracia e a alta carga tributária, irá implantar uma política pública eficaz e consistente para os pequenos. (REVISTA VENCER, 2005, p. 70).

Esta fala reflete historicamente a busca, ou mesmo disputa, empreendida pelo SEBRAE, por condições favoráveis para os pequenos negócios. $O$ ato de organizar uma lei desse porte e de lutar abertamente para sua implementação, põe em relevo, a posição de porta-voz dos "pequenos". Atualmente, no website do SEBRAE, há o que eles denominam de "Frente Empresarial" em prol da aprovação desta lei, tendo um abaixo assinado eletrônico a ser endossado pelos visitantes. Esse será encaminhado ao governo, mostrando o interesse da sociedade no assunto. Isto representa bem mais, em nosso entender, pois perfaz a aglutinação de uma vontade coletiva em torno não só da aprovação de uma lei, mas do reconhecimento do SEBRAE, enquanto o grande e até único interlocutor. Posição compreensível, para quem veio historicamente consolidando uma postura institucional em favor das MPE, e sabe que precisa produzir e reproduzir constantemente sua ideologia para se manter hegemônico.

No tocante ao empreendedorismo, Paulo Okamotto destaca a partir das pesquisas do Global Entrepreneurship Monitor vii (GEM), dois conceitos afins ao tema:

[...] a pesquisa GEM demonstra que algumas das causas da alta taxa de empreendedorismo no Brasil estão nas nossas históricas mazelas socioeconômicas. É o caso de empreender por necessidade, cujos índices, como revela a pesquisa relativa a 


\section{trabalhonecessário}

issn: $1808-799 \mathrm{X}$

ano 7 - número 8 - 2009

2004, embora menores do que a atividade empreendedora por oportunidade, continuam elevados, registrando a proporção de $46 \%$. Nos países desenvolvidos, de TEA em vários casos bem menor do que a brasileira, empreende-se bem mais por oportunidade, como na Alemanha, Itália e Austrália. Deve-se ressaltar, ainda, no nosso caso, a baixa educação formal, com apenas $14 \%$ com formação superior, contra $23 \%$, em média, nos países com renda semelhante à nossa, e 30\% sem completar o ensino fundamental. (REVISTA VENCER, 2005, p. 71, grifos nossos).

Estes dois conceitos destacados que se referem ao tipo de empreendedorismo que se encontra em cada país são retirados do GEM e assim são compreendidos. O "empreendedorismo por oportunidade" é compreendido sem muita dificuldade, pois representa a atividade realizada por vontade própria. Já o "empreendedorismo por necessidade" é realizado por aqueles indivíduos que [...] não têm condições de encontrar qualquer outro trabalho que lhes pareça conveniente (GEM, 2002, p. 04). Ainda sobre estes tipos de empreendedorismo o GEM destaca que os empreendedores motivados por oportunidade predominam em países desenvolvidos e que os motivados pela necessidade se encontram nos países em desenvolvimento, ou seja, os situados nos países de capitalismo periférico.

Na visão do Sebrae, empreender vai além de instalar o próprio negócio. Empreender é também criar, é ser pró-ativo, é liderar. Por isso, a atitude empreendedora perpassa quase todos os nossos produtos, projetos e programas. Como já vimos, o brasileiro é um empreendedor nato. Ele precisa é que sejam dadas melhores condições para montar o próprio negócio com sucesso. O ideal era que, na proporção entre empreender por necessidade e pela oportunidade, a última alternativa fosse bem mais preponderante e tivesse mais peso, em vez dos $54 \%$ registrados no ano passado. O sujeito que empreende por necessidade não tem alternativa. (REVISTA VENCER, 2005, p. 71).

Assim, a falta de conhecimento e o ambiente perverso representariam os grandes obstáculos para os empreendedores "natos". No caso, como vimos anteriormente, o tipo de empreendedorismo que o Brasil detém confere ao brasileiro 


\title{
trabalhonecessário
}

issn: $1808-799 \mathrm{X}$

ano 7 - número 8 - 2009

uma inerência ao tema. Ao que parece estar alijado das condições básicas de existência beneficia e possibilita esta inerência. Dando seguimento à fala do diretorpresidente:

\begin{abstract}
Além de melhorar o ambiente externo, como já abordamos, é preciso sobretudo qualificar melhor o empreendedor. Nossa pesquisa sobre a mortalidade das micro e pequenas empresas revelou que, entre aquelas que encerraram as atividades de 2000 a 2004, apenas 3\% procuraram e Sebrae. A mesma pesquisa detectou como um dos principais fatores da mortalidade as falhas gerenciais, como falta de planejamento e de conhecimento de gestão de mercado. As empresas morrem porque nascem mal. Deveriam nascer bem para poder sobreviver. (REVISTA VENCER, 2005, p. 71).
\end{abstract}

Ponto importante, em destaque, se refere à questão educativa do empreendedor. Neste sentido o SEBRAE tem se colocado como o grande beneficiário dos "pequenos", promovendo a educação empreendedora necessária à criação das MPE.

Assim, o Conselho deliberativo do SEBRAE objetivando atender esta demanda em conjunto com outras estabeleceu as seguintes prioridades estratégicas ${ }^{\text {viii }} \mathrm{e}$ correspondentes ações para o período 2003/2005:

- reduzir a carga tributária e a burocracia;

- ampliar e universalizar o crédito e a capitalização;

- promover a educação empreendedora e cooperação;

- promover o acesso à tecnologia e estimular a inovação;

- promover o acesso a mercados;

- atuar em ações coletivas e priorizar Arranjos Produtivos Locais;

- aprimorar a estrutura, operação e a gestão do SEBRAE. 


\section{trabalhonecessário}

issn: $1808-799 \mathrm{X}$

ano 7 - número 8 - 2009

No que tange ao objetivo de promoção da educação empreendedora, matéria que interessa ao presente estudo, o SEBRAE têm como objetivos;

A) Disseminar a cultura do empreendedorismo e da cooperação em todos os níveis da educação formal e nos diversos meios de comunicação. B) Articular a formação e o fortalecimento de redes e organizações de cooperação dos pequenos empreendimentos. C) Articular, desenvolver e implementar programas de gestão empresarial, da cultura do empreendedorismo, de cooperação e, de capacitação de lideranças e executivos de organizações e de MPE. (website do SEBRAE, 2005).

Enfim, por estes objetivos, podemos perceber que o empreendedorismo tem ganhando espaço nas atenções do SEBRAE, no que tange a sua implementação acrítica no seio escolar, como forma de atender às demandas de formação humana para o mercado de trabalho. Neste sentido, sua atuação tem sido notória no que se refere à implementação de cursos em escolas, para desenvolver o espírito empreendedor. Goulart e Filho ao tratar sobre as inferências do empreendedorismo para a educação destacam que:

No Brasil os trabalhos sobre empreendedorismo têm sido, com freqüência, associados ao desenvolvimento de empreendedores e de empreendimentos, e seu palco privilegiado é o SEBRAE nos diversos Estados. (GOULART E FILHO, 2004, p. 103).

Assim, o SEBRAE tem sido um dos principais fomentadores do empreendedorismo na educação, com a realização de cursos voltados para a escola. Um destes cursos é o Programa de Formação de Jovens Empreendedores destinados aos alunos do ensino médio que trataremos a seguir.

\section{O Programa de Formação de Jovens Empreendedores do SEBRAE}

O Programa de Formação de Jovens Empreendedores, do Sistema Brasileiro de Apoio às Micro e Pequenas Empresas (SEBRAE), é um curso desenvolvido em escolas, tendo o intuito de disseminar a cultura empreendedora na sociedade, 


\section{trabalhonecessário}

issn: $1808-799 \mathrm{X}$

ano 7 - número 8 - 2009

objetivando adaptar (e conformar) os indivíduos, à nova realidade econômica do país (DIAS, 2006). De acordo com informações no website ${ }^{i x}$ do SEBRAE, desde 2004, o curso já atingiu 652 professores, 6.130 alunos do ensino médio e cerca de 72 instituições (escolas públicas e privadas) do Estado do Rio de Janeiro. Para o ano de 2006, cerca de 26 mil alunos do ensino médio da rede pública da Grande São Paulo passarão pelo curso.

Atualmente o SEBRAE, desenvolveu outro curso denominado de Programa de Formação de Empreendedores - "Primeiros Passos" destinado aos alunos do ensino fundamental ( $1^{\mathrm{a}}$ a $8^{\mathrm{a}}$ séries), com idade entre 07 a 14 anos. Nas palavras do SEBRAE': O programa foi desenvolvido para atender ao grande desafio do Ensino Fundamental nos dias atuais, que não se limita a alfabetizar e dar formação básica, mas preparar o aluno para as situações apresentadas em seu futuro (SEBRAE, 2006).

No tocante aos limites do nosso estudo, vamos nos ater ao curso voltado para o ensino médio. Apenas estamos destacando este curso, para o ensino fundamental, como forma de mostrar o empenho do SEBRAE em desenvolver o empreendedorismo, no chão da escola, e em séries cada vez mais iniciais.

Apoiado em Schumpeter, o SEBRAE, em meados de 1990, estrategicamente, agregou esta concepção de empreendedorismo, de forma a convencer a sociedade brasileira de que, no bojo da economia de mercado, a instabilidade da vida impõe respostas e adaptações que podem ser promovidas pelo espírito empreendedor.

No presente século, o enfoque do empresário empreendedor como fator dinâmico de expansão das economias de mercado é resgatado ao nível da teoria econômica de Joseph Schumpeter, para quem o estímulo para o início de um novo ciclo econômico, assenta-se principalmente nas inovações tecnológicas introduzidas por esta categoria de empresário. Nesses termos, Schumpeter apresenta-nos o conceito de destruição criadora, que fundamenta-se no princípio de que o papel do empresário empreendedor é justamente $\mathrm{o}$ de propiciar a quebra de paradigmas nas economias de mercado estabelecendo novos patamares econômicos e tecnológicos nas suas estruturas- 


\section{trabalhonecessário}

issn: $1808-799 \mathrm{X}$

ano 7 - número 8 - 2009

produtivas, sempre na busca de lucro e de realização profissional e individual. (SEBRAE, 1995, p. 02).

E, para se tornar empreendedor, é necessário que o indivíduo adquira e aprimore constantemente suas qualidades pessoais, pois a consecução de um negócio lucrativo, na perspectiva apontada por Schumpeter, é de cunho pessoal.

Conhecer a si mesmo como empreendedor é um dos aspectos mais importantes para o sucesso de um negócio, pois pode-se ser a ferramenta do próprio trabalho [...]. Cada um deve, então, avaliar suas próprias características o mais objetivamente possível e encarar corajosamente suas limitações, trabalhando seriamente para desenvolver aquelas características de que se necessita [...]. Somos um "produto" em constante estado de aperfeiçoamento. Se hoje somos o que somos amanhã seremos o que quisermos ser. Algumas características nossas não poderão variar em grau de desenvolvimento, em qualidade em importância e no espaço que ocupam em nossas vidas. (SEBRAE, 1995, p. 43).

Nossos referenciais de análise, numa perspectiva crítica, serão as noções de competência e empregabilidade estudadas por Ramos (2001a) e, que, guardam coerência com a noção de empreendedorismo, como veremos.

Nosso objetivo é qualificar a concepção de homem e mundo que o ensino do empreendedorismo nas escolas, infere nos professores e alunos. A partir disto, também qualificaremos a pedagogia empreendedora presente neste curso do SEBRAE, dentro das categorizações que Saviani (2005) propôs acerca das teorias da educação que são: as teorias não-críticas, crítico-reprodutivistas e crítica. Não obstante, iniciaremos por tratar do programa de Formação de Jovens Empreendedores do SEBRAE.

O Programa de Formação de Jovens Empreendedores é um curso desenvolvido e promovido pelo SEBRAE, visando à formação de jovens empreendedores. Está sendo oferecido às escolas (públicas ou privadas) para os alunos do ensino médio. 


\section{trabalhonecessário}

issn: $1808-799 \mathrm{X}$

ano 7 - número 8 - 2009

Pela Visão Geral| deste programa, o "mundo está mudando, e o sucesso será fruto da capacidade de utilizar forma racional e inovadora as potencialidades emergentes de uma nova era, a era do empreendedorismo" (2004).

Diante disto, o SEBRAE projeta para a escola, enquanto principal instituição formadora, as demandas na formação de empreendedores, que numa conjuntura de "diminuição" de postos de trabalho, se torna essencial à esfera produtiva e ao capital.

O curso tem uma característica extracurricular sendo oferecido na escola fora do turno do aluno. O curso é ministrado pelos professores da própria unidade escolar que de antemão já receberam uma capacitação de 64 horas, dos instrutores do SEBRAE. Esta capacitação visa a instrumentalização dos professores no uso do material didático, como as apostilas ou módulos (I, II e III). Há os módulos do professor, ou melhor, multiplicador, com o detalhamento (pari passu) de cada aula a ser acompanhada nos respectivos módulos dos alunos. O treinamento dos alunos tem uma duração programada de 96 horas.

Assim se por um lado as demandas colocadas pela acumulação flexível (Harvey, 1993), precisam de um novo modelo de trabalhador (dotado de competências) necessário no interior das empresas. De outro lado é de suma importância indivíduos empreendedores ${ }^{\text {xii }}$ que tenham condição de atuar fora destas últimas.

No tocante a estas disciplinas e aos objetivos do presente texto, iremos nos ater as disciplinas do Treinamento Motivacional (Módulo 1), pois perfazem imediatamente na formação do espírito empreendedor. Neste sentido, o nosso objeto empírico será o Módulo 1 - aluno, no qual encontraremos referências á noção de competência e empregabilidade, que nos auxiliaram na compreensão do empreendedorismo. 


\section{trabalhonecessário}

issn: 1808-799X

ano 7 - número 8 - 2009

\section{Análise do programa de Formação de Jovens Empreendedores}

Neste momento, iremos empreender a análise da apostila módulo 1 - aluno, de forma a destacar a convergência de seu conteúdo com as noções de competência e empregabilidade de maneira a qualificar na sua proposta de formação a concepção de homem emanada do curso.

De imediato já iniciamos a análise destacando a estrutura curricular do curso. Ele está configurado na seguinte estrutura: Treinamento Motivacional (Módulo 1), Planejamento do Negócio (módulo 2) e Constituição da Empresa (Módulo 3). No início deste texto já anotamos as características de cada módulo e que nos servirá de análise. Pois como vimos o módulo 1, congrega comportamentos e atitudes que impliquem em despertar e reforçar o espírito empreendedor. Já os outros dois módulos apresentam-se numa perspectiva de saberes mais formais ${ }^{\text {xiii }}$, sobre noções de economia, tributos, normas e leis afins a constituição de uma pequena empresa.

Numa primeira análise, este currículo perfaz a concepção de formar não só por uma base técnica, mas também numa perspectiva de desenvolvimento de competências que é da forma como compreendemos o módulo 1 e que veremos a seguir.

A apostila referente ao módulo 1 - aluno é constituído de material impresso referente às três disciplinas: Desenvolvimento Comportamental (10 aulas, p. 01-33), O Empreendedor (08 aulas, p 01-30) e Ciclo de Vida das Pequenas Empresas (09 aulas, $p$ 01-46). Em todas as disciplinas, observamos a abordagem dos conteúdos seguida de atividades de vivências, dinâmicas, jogos teatros; referentes aos assuntos abordados. Além destes, observamos fragmentos de textos com relatos de experiências de sucesso e fracasso, bem como trechos de reportagens de jornais enfatizando a necessidade e importância do empreendedorismo ante as mudanças ocorridas no mundo. 


\section{trabalhonecessário}

issn: $1808-799 \mathrm{X}$

ano 7 - número 8 - 2009

Passaremos agora a análise do material das disciplinas Desenvolvimento Comportamental e O Empreendedor, procurando destacar as noções e competência e empregabilidade, de forma a obtermos suporte teórico e empírico para qualificarmos este curso de empreendedorismo do SEBRAE, que também nomearemos de pedagogia empreendedora. No material da disciplina Desenvolvimento Comportamental, destacaremos algumas aulas que fazem referência a competência.

$\mathrm{Na}$ aula 04 é dissertado sobre uma importante competência, que é a criatividade. "O indivíduo criativo hoje não é só aquele, que intui, mas aquele que, além de imaginar, tem a capacidade de dar utilidade à sua criação" $(2004$, p. 08). Aqui se faz referência a mobilização da criatividade para a ação, um importante componente da concepção de competência, inerente ao empreendedor que terá que criar o seu "auto-emprego" para sobreviver no mercado.

$\mathrm{Na}$ aula 06 da apostila, destaca-se a importância de se desenvolver habilidades para negociar e resolver conflitos. "Levando em conta que vivemos constantemente em relações sociais, a habilidade em resolver conflitos é fundamental para uma convivência mais produtiva e harmoniosa" (idem, p. 15). Aqui é ressaltada importância de saber ser um bom negociador para gerar produtividade e um espaço social harmonioso, numa perspectiva bem acrítica de conceber a realidade, como se os problemas gestados no ambiente social pudessem ser resolvidos individualmente pela negociação.

$\mathrm{Na}$ aula 07 faz-se um destaque para a importância da Autonomia, como forma do indivíduo entrar em contato com o poder de criar a própria realidade. Neste sentido, ressalta-se a necessidade da pessoa por em jogo sua subjetividade para produzir sua realidade. As transformações que se ensejam são de cunho individual e privado.

$\mathrm{Na}$ aula 08, faz-se um destaque à Inovação enquanto característica essencial e inerente ao empreendedor. 


\section{trabalhonecessário}

issn: $1808-799 \mathrm{X}$

ano 7 - número 8 - 2009

Temos a tendência à acomodação, não queremos ter o trabalho de viver cada segundo como uma situação única, que merece respostas únicas de nossa parte. Ale, disso tememos abandonar o já conhecido, enfrentando o temeroso desconhecido. Por isso criamos padrões repetitivos de conduta, usando sempre as mesmas estratégias, não importando se as situações são diferentes. Mudanças fazem parte da dinâmica da vida, tanto pessoal como profissional, e hoje a tendência é que as mudanças se tornem mais freqüentes e intensas. (p. 19).

No sentido acima aludido, o indivíduo forçosamente terá de se tornar inovador para se adaptar ao mundo, gerando diferentes respostas para as diferentes situações impostas pela realidade. E acrescenta: inicie o processo de mudança por você. Essa é a maior de todas as revoluções possíveis (p. 20). Nesta perspectiva, o processo de revolução é de caráter individual e só possível via subjetividade. A intenção é de camuflar a possibilidade da luta de classes, em prol da perspectiva individualista, como se fosse impossível uma revolução coletiva.

Na aula 11, o tema tratado é "Empregabilidade: o desfio do fim do emprego". Em seu conteúdo, procura-se ressaltar que o mundo caminha para o "fim do emprego", pois as mudanças tecnológicas vão criando desempregados da noite para o dia e determinadas funções vão simplesmente deixando de existir.

Hoje, nas metalúrgicas da Europa, já não existe a função de soldador. Os robôs fazem isto. Mais próximo de nós, o Brasil, após várias demissões, ainda tem 600 mil bancários e este número será reduzido, em um ano, a 200 mil. A automação vai substituir o CAIXA, e esta função vai deixar de existir. E quantas outras profissões virão no seguimento e não existirão mais? Mais do que posição, título e cargo, sua empregabilidade representa seu bem mais valioso. (p. 30).

E qual a compreensão de empregabilidade contido na apostila?

É o conjunto das suas habilidades, conhecimentos e capacitações que determinará se você será mantido na organização ou terá que buscar oportunidades fora. É aprimorar os seus talentos [...] Conceitos como função, atividades e resultados são a chave da 


\section{trabalhonecessário}

issn: $1808-799 \mathrm{X}$

ano 7 - número 8 - 2009

moderna empregabilidade. Hoje o mercado tem que ser olhado pelo profissional como um conjunto de oportunidades de trabalho. Terá mais aquele que tiver coragem de empresariar a si mesmo, de vender sua competência, de investir em cursos de atualização, na sua própria reciclagem. (p. 30).

Aqui observa uma perspectiva ideológica, no sentido marxista de falseamento da realidade, como nos leva a entendimento Chauí:

A ideologia é um conjunto lógico, sistemático e coerente de representações (idéias e valores) e de normas ou regras (de conduta) que indicam e prescrevem aos membros da sociedade $o$ que devem pensar e como devem pensar, o que devem sentir e como devem sentir, o que fazer e como devem fazer [...] cuja função é dar aos membros de uma sociedade dividida em classes uma explicação racional para as diferenças sociais, políticas e culturais, sem jamais atribuir tais diferenças à divisão da sociedade em classes a partir da esfera das divisões na esfera da produção. (2004, p. 108).

Nesta concepção, o discurso da apostila do SEBRAE procura enfatizar que as mudanças tecnológicas são as responsáveis únicas e inevitáveis do desemprego. Assim destacando só processo e não o seu agente, o capital, que produz toda esta realidade de desemprego. Infere-se o entendimento de que este processo é natural ao desenvolvimento tecnológico cabendo aos indivíduos se adequarem às mudanças postas em condições dadas. Essa perspectiva ideológica infere também de que não há resistência da classe trabalhadora frente ao desemprego. Utilizando o exemplo dos bancários, afirma-se que os empregos vão desaparecer pura e simplesmente, com o passar do tempo, silenciando a luta que os trabalhadores bancários e de outras categorias, tem travado para contrapor a este processo.

O que fica expresso no discurso apologético do SEBRAE é que a saída é individual, cabendo as pessoas se adequarem ao mercado, aprimorando seus talentos, enquanto saída única para resolver o problema do desemprego. É adquirindo competências que o indivíduo poderá dotar-se de empregabilidade como forma de tornar-se empregado ou adquirir competências que impliquem na 


\section{trabalhonecessário}

issn: $1808-799 \mathrm{X}$

ano 7 - número 8 - 2009

oportunidade de "empresariar a si mesmo", no formato do empreendedorismo. Assim, as noções de empregabilidade e empreendedorismo são destacadas como modo de contrapor ao drama do desemprego, dado como inelutável. Procura-se, com isso, camuflar a possibilidade de contraposição coletiva da classe trabalhadora na perspectiva de transformação social.

Pela disciplina "O Empreendedor". As aulas 01,02 e 03 congregam um conjunto de conhecimentos focalizados na psicologia e tangente ao desenvolvimento da personalidade, de forma a dar subsídio à compreensão do empreendedor.

$\mathrm{Na}$ aula 04, "Características do Empreendedor" procura-se dar maior compreensão sobre o empreendedor.

Empreendedores são pessoas que perseguem o benefício, trabalham individual e coletivamente. Podem ser definidos como indivíduos que inovam, identificam e criam oportunidades de negócios, montam e coordenam novas combinações de recursos (funções de produção), para extrair os melhores de suas inovações num meio incerto. (p. 12).

Um destaque que a apostila faz é que a personalidade do empreendedor incidirá diretamente no sucesso ou fracasso da nova empresa. Assim, a subjetividade tem fator decisivo para o empreendedor, o que a nosso ver perfaz a concepção de competência. Nesta linha, os elementos subjetivos são postos como responsáveis pelo sucesso ou fracasso não levando em conta a realidade contraditória e historicamente produzida, o que espraia a perspectiva de responsabilidade individual sobre qualquer acontecimento no negócio do empreendedor, o que infere também em conceber o desemprego como falha individual ou indisposição de que quem não soube empreender.

No rol destas características é possível identificar várias competências referentes às demandas impostas pelas transformações na base produtiva, e aqui são descritas como habilidades, a nosso ver são competências. Por que estamos dizendo isto? Pois se nos basearmos em Zabala (1998) a competência representa a 


\section{trabalhonecessário}

issn: $1808-799 \mathrm{X}$

ano 7 - número 8 - 2009

capacidade de a pessoa mobilizar saberes, conhecimentos, habilidades e atitudes para resolver problemas e tomar decisões, na linha do trio saber, saber-fazer e saber-ser, destacados por Ramos (2001a). A habilidade representaria uma dimensão, a do saber-fazer, enquanto uma das dimensões da competência.

"Valorização de oportunidades e pensamento criativo". A avaliação seria de fundamental importância para distinguir as oportunidades reais e as falsas. Para tal, seria necessário o empreendedor pensar criativamente e fazer uma valoração das oportunidades que surgem.

"Comunicação Persuasiva". No geral, os empreendedores iniciam com nada além do que uma idéia. Para transformá-la em algo concreto, necessitam convencer outras pessoas (amigos, parentes, desconhecidos) a se associarem, investindo ou emprestando dinheiro. Precisa convencer fornecedores a oferecer crédito e precisa convencer os consumidores de seu novo produto ou serviço.

"Negociação". Negociar se torna essencial ao empreendedor para que seu novo negócio possa materializar-se.

A habilidade para negociar, com as outras [pessoas], se adquire pela experiência. Está intimamente relacionada com aspectos de origem cultural. É freqüente ouvir que as pessoas de origem árabe são bons negociantes. Muitos desenvolvem esta habilidade desde criança, uma vez que nos países árabes o comércio é praticado sem preços fixos a priori [...]. O comprador deve sempre negociar o preço final com o vendedor (p. 22).

"Aquisição de Informações". Tornar-se imprescindível ao empreendedor, estabelecer habilidades de aquisição de informação, adaptando-se ao ambiente instável e competitivo, a partir dos avanços nos processo gerenciais e tecnológicos. Aqui mais uma vez a referência à adaptação à realidade ao invés de transformá-la.

Novamente, há que se destacar a dinâmica da sociedade atual. Esta exige dos empresários produtos e serviços com mais qualidade, preços menores e garantias maiores. Também a 


\section{trabalhonecessário}

issn: $1808-799 \mathrm{X}$

ano 7 - número 8 - 2009

economia globalizada submete os empresários à concorrência internacional. Portanto, o empreendedor só manterá a sua empresa se estiver atento às exigências e suficientemente informado para adotar as modificações necessárias para enfrentar a nova realidade. (p. 22).

"Resolução de problemas". A resolução de problemas é de fundamental importância, segundo o SEBRAE, na abertura e desenvolvimento de um novo negócio. Pois, "[...] cada novo negócio gera um conjunto único de problemas, desafios e crises" (p. 22). Neste sentido, o empreendedor tem que aprender a identificar o problema.

Sendo assim, a partir da exploração feita nas apostilas das disciplinas "Desenvolvimento Comportamental" e "O empreendedor" do módulo 1 - aluno, pudemos constatar que há uma convergência entre as noções de competência e empregabilidade que nos habilita a qualificarmos a presente pedagogia empreendedora do SEBRAE.

Observamos claras referências à concepção de competência ressaltando aspectos psicológicos, fazendo menção à subjetividade e a experiência; como sendo base para a constituição do espírito empreendedor. Ressalta inclusive a importância de algumas competências, como a criatividade, autonomia, criticidade, resolução de problemas, comunicação, inovação, entre outras.

O caráter do curso ao promover jogos, atividades e dinâmicas, de forma aos alunos vivenciarem os conteúdos tratados, comunga com a dimensão experimental da competência, no que tange as capacidades cognitivas e sócio-afetivas a serem trabalhadas.

Neste sentido, pode-se afirmar que a pedagogia empreendedora, ensejada no curso de Formação de Jovens Empreendedores do SEBRAE, tem como base a pedagogia das competências. $E$ isto nos dá suporte para dizermos que a pedagogia empreendedora do SEBRAE tem como perspectiva histórica à adaptação do ser humano a sociedade capitalista, desconsiderando qualquer possibilidade de transformação radical deste modelo de sociedade. 


\section{trabalhonecessário}

issn: $1808-799 \mathrm{X}$

ano 7 - número 8 - 2009

Nesta concepção, o capitalismo é encarado como o único modo de produção possível cabendo as pessoas inserirem-se de modo adaptativo as demandas impostas pelo mercado. O seu discurso do empreendedorismo assevera, com tonicidade, o consenso na medida em que enseja nas pessoas a possibilidade de se tornarem patrões ao invés de empregados ou desempregados. Neste sentido, não seria necessária uma transformação radical da sociedade, pois ser empreendedor seria a saída para resolver, individualmente, os problemas econômicos e sociais postos pelo próprio capitalismo. Camufla-se desta forma, que ser empreendedor, ao contrário, insere-se na precarização das condições de trabalho e existência na qual o indivíduo não possui qualquer segurança ou perspectiva futura.

O que se observa no discurso do empreendedorismo é a precarização do trabalho, que compreendemos com Irene Galeazzzi (2002) como sendo uma diversidade de situações laborais que se afastam do padrão de emprego assalariado, regido por leis e condições de trabalho determinadas.

Ser empreendedor é ser precarizado, pois na perspectiva do "auto-emprego", ele não usufrui nenhum dos diretos assegurados para o trabalhador assalariado, como as férias, remuneração nos períodos de parada de trabalho por enfermidade, descanso remunerado, seguro desemprego, aposentadoria, etc. Todo e qualquer benefício, nesta linha, deverá ser financiado pelo próprio trabalhador, que, geralmente, não ganha rendimentos que the permitam custear parte destes benefícios similares à de um trabalhador assalariado (GALEAZZI, 2002).

Neste sentido, na medida em que a noção de competência adquire materialidade na pedagogia empreendedora do SEBRAE ela também comunga da mesma concepção de homem natural-funcionalista que deságua numa concepção subjetivo-relativista de conhecimento. Pela concepção de homem o assevera a adaptação aos ditames impostos pelo mercado ao mesmo passo que satisfaz o consenso necessário à manutenção do sistema capitalista, pois na visão apologética, não há alternativa. 


\section{trabalhonecessário}

issn: $1808-799 \mathrm{X}$

ano 7 - número 8 - 2009

Com base nestas considerações, iremos qualificar a pedagogia empreendedora do SEBRAE, via Programa de Formação de Jovens Empreendedores, segundo os grupos das tendências pedagógicas desenvolvidas por Saviani em sua obra Escola e Democracia (2005). De acordo com Saviani as teorias da educação podem ser qualificadas em três grupos, de acordo com compreensão do papel que exercem na sociedade. São estes grupos, a saber: Teorias Não-críticas, Teorias Crítico-Reprodutivistas e Teoria Crítica.

Uma teoria que podemos ingressar no grupo da teoria crítica é a pedagogia histórico-crítica que vem sendo desenvolvida por Saviani nas suas obras Pedagogia Histórico-crítica: primeiras aproximações (1997) e Escola e Democracia (2005).

A partir da exposição feita sobre a categorização feita por Saviani (2005), nós acrescentaríamos a pedagogia empreendedora do SEBRAE ao grupo das teorias não-críticas, pois esta tem ingressado na escola, numa perspectiva acrítica e formadora do consenso em torno do sistema capitalista ao passo que vai silenciando qualquer perspectiva de transformação radical da sociedade.

Nos limites desta exposição, acreditamos poder concluir que a noção de empreendedorismo, que tem apontado para uma pedagogia empreendedora para a educação, tem como base a pedagogia das competências. $E$ isto nos dá suporte para dizermos que a esta pedagogia empreendedora tem como perspectiva histórica a adaptação do ser humano à sociedade capitalista, desconsiderando qualquer possibilidade de transformação radical deste modelo de sociedade.

Assim somos contrários à perspectiva conformadora da pedagogia empreendedora que tem ganhado espaço na educação enquanto mote para se adequar às mudanças exigidas pelo mercado. Congregamos uma outra perspectiva de formação calcada numa concepção marxista de formação humana e na qual a área da educação tem buscado desenvolver. 


\section{trabalhonecessário}

issn: $1808-799 \mathrm{X}$

ano 7 - número 8 - 2009

\section{Referências Bibliográficas:}

ANTUNES, Ricardo. Os Sentidos do Trabalho - Ensaio sobre a afirmação e a negação do Trabalho. São Paulo: Boitempo, 1999.

A Desertificação Neoliberal no Brasil (Collor, FHC e Lula). Campinas, SP: Autores Associados, 2004.

BOITO Jr., Armando. Política Neoliberal e Sindicalismo no Brasil. São Paulo: Xamã, 1999.

CAMPOS, Marilene de Souza. A Empresa como Vocação: O SEBRAE e o Empreendedorismo na Cultura da Informalidade como Problema Público. Tese de Doutorado. Rio de Janeiro: IUPERJ, 2003.

CHAUÍ, Marilena. O que é Ideologia. São Paulo: Braziliense, (Coleção primeiros passos; 13), 2004.

DIAS, Graziany Penna. Empreendedorismo e Educação: o SEBRAE na Escola. Dissertação de Mestrado. Niterói-UFF, 2006.

Estudo EXAME - Inovação e Empreendedorismo: o valor das pessoas no desafio de inovar. Revista EXAME. São Paulo, ano 40, nº 06, 29 de março de 2006.

FRIGOTTO, Gaudêncio. A Produtividade da Escola Improdutiva. - 6a ed. - São Paulo: Cortez, 2001.

GALEAZZI, Irene. Precarização do Trabalho. In: CATTANI, Antonio David (org.). Dicionário Crítico sobre Trabalho e Tecnologia - 4 ed. rev. ampl. - Petrópolis: Vozes; Porto Alegre: Ed. da UFRGS, 2002, p. 242-247.

GLOBAL ENTREPRENEURSHIP MONITOR. GEM Brasil 2002. Executive report. London, 2002.

GOULART, Íris Barbosa e FILHO, Sudário Papa. Empreendedorismo e Empreendedores: sugestões para Educação. Belo Horizonte/MG: Editora Newton 


\section{trabalhonecessário}

issn: $1808-799 \mathrm{X}$

ano 7 - número 8 - 2009

Paiva, 2004.

GOUNET, Thomas. Fordismo e Toyotismo na Civilização do Automóvel. São Paulo: Boitempo, 1999.

HARVEY, David. Condição Pós-Moderna. São Paulo: Editora Loyola, 1993.

JF perde 200 postos por falta de mão-de-obra qualifica. Jornal Tribuna de Minas, Juiz de Fora, p. 03, 22 e 23 de maio de 2005.

KOSIK, Karel. Dialética do Concreto. - $7^{\text {a }}$ ed. - Rio de Janeiro: Paz e Terra, 1976.

MINARELLI, José Augusto. Empregabilidade: o caminho das pedras. São Paulo: Editora Gente, 1995.

OKAMOTTO, Paulo. Temos um ambiente perverso para as pequenas empresas. Vencer. São Paulo: Editora VENCER, ano VI, nº. 67, 2005.

OLIVEIRA, Ramon de. Empregabilidade e Competência: conceitos novos sustentando velhos interesses. Revista no NETE - Trabalho e Educação - jan/jul 1999, nº5, p50-63.

POMBO, Adriane Alvarenga da Rocha. O Que é Ser Empreendedor. Documento adquirido na Biblioteca Temática do Empreendedor - SEBRAE. Website: http//:www.bte.com.br. Acessado dia 20/11/2005.

RAMOS, Marise Nogueira. Da qualificação à competência: deslocamento conceitual na relação trabalho - educação. Tese de doutorado, UFF: Niterói, 2001a.

A Pedagogia das Competências: Autonomia ou Adaptação? São Paulo: Cortez, 2001b.

Os Limites da Noção de Competência sob a perspectiva da Formação Humana. In: Movimento: revista da Faculdade de Educação da Universidade Federal Fluminense, Niterói: Intertexto n 04, set. 2001c, p. 47-64.

RODRIGUES, José. Da Teoria do Capital Humano à Empregabilidade: um ensaio 


\section{trabalhonecessário}

issn: $1808-799 \mathrm{X}$

ano 7 - número 8 - 2009

sobre as crises do capital e a educação. Revista do NETE - Trabalho e Educação ago/dez - 1997, nº 02 p. 215- 230.

SAVIANI, Dermeval. Pedagogia Histórico-crítica: primeiras aproximações. - $6^{\mathrm{a}}$ ed. Campinas, SP: Autores Associados (Coleção Polêmicas do Nosso Tempo), 1997.

. Escola e Democracia. - $37^{\mathrm{a}}$ ed. - Campinas, SP: Autores Associados (Coleção Polêmicas do Nosso Tempo), 2005.

SEBRAE. Criando seu próprio negócio: como desenvolver o potencial empreendedor. São Paulo: USP e Edições Sebrae, 1995.

. SEBRAE 30 Anos parceiro dos brasileiros/José Humberto Marcuso. Brasília: SEBRAE Nacional, 2002.

. Formação de Jovens Empreendedores chega à rede pública de ensino. Disponível em: www.sebraesp.com.br. Acessado dia 04/02/2006.

. SEBRAE/RJ leva lição de empreendedorismo a alunos da $1^{\mathrm{a}}$ a $8^{\mathrm{a}}$ séries. Disponível em: www.sebraerj.com.br. Acessado dia 04/02/2006.

. Formação de Jovens Empreendedores. Módulo 1 - Aluno. 2002.

. Formação de Jovens Empreendedores. Módulo 2 - Aluno. 2002.

. Formação de Jovens Empreendedores. Módulo 3 - Aluno. 2002.

. Formação de Jovens Empreendedores. Módulo 1 - Professor. 2002.

. Formação de Jovens Empreendedores. Módulo 2 - Professor. 2002.

. Formação de Jovens Empreendedores. Módulo 3 - Professor. 2002.

SCHUMPETER, Joseph A. Teoria do Desenvolvimento Econômico. Rio de Janeiro: Ed. Fundo de Cultura, 1961a.

. Capitalismo, Socialismo e Democracia. Rio de Janeiro: Fundo de Cultura, $1961 \mathrm{~b}$. 


\section{trabalhonecessário}

issn: $1808-799 \mathrm{X}$

ano 7 - número 8 - 2009

SINGER, Paul. Globalização e Desemprego: diagnósticos e alternativas - $6^{\mathrm{a}}$ ed. São Paulo; Contexto, 2003.

SOUZA, Donaldo Bello de; SANTANA, Marco Aurélio e DELUIZ, Neise. Trabalho e Educação: Centrais Sindicais e Reestruturação produtiva no Brasil. Rio de Janeiro: Quartet, 1999.

ZABALA, Antoni. A Prática Educativa: como ensinar. Porto Alegre: Artmed, 1998.

\footnotetext{
' Professor Mestre da rede municipal de Juiz de Fora/MG e tutor a distância no curso de Pedagogia, disciplina Sociologia da educação, pela UAB/UFJF.

ii Pesquisa sob a orientação do prof. Dr. José dos Santos Rodrigues.
}

iii Homo oeconomicus é um conceito gestado pela economia burguesa, que compreende o homem enquanto um conjunto de faculdades a serem constituídas nos indivíduos para que o sistema econômico possa funcionar. A realidade é dada naturalmente, cabendo a este homo oeconomicus descobrir as leis que a regem e adequar-se a elas para maximizar os seus ganhos. $O$ homem, neste sentido, se reduz a uma abstração genérica, a-histórica e cujas características básicas são a racionalidade do comportamento e o egoísmo. Para saber mais ver Kosik (1976) e Firgotto (2001).

iv Fênix era uma ave do fogo da mitologia grega, que ao envelhecer e morrer (se desfazendo em cinzas) renascia jovem e revigorada para mais um período de existência.

${ }^{\vee}$ Respectivamente: Serviço Nacional de Aprendizagem Industrial, Serviço Nacional de Aprendizagem Comercial, Serviço Social da Indústria e Serviço Social do Comércio.

vi Vencer. São Paulo: Editora VENCER, ano VI, n. 67, 2005. London Business School e Babson College, indica que o Brasil está entre os países que mais empreendem no mundo.

vii É um relatório internacional sobre um programa de pesquisa realizado em vários países com o intuito de compreender melhor o fenômeno do empreendedorismo. Nas palavras do mesmo "[...] representa uma experiência extraordinária e sem precedentes, que descreve e analisa processos empreendedores, cobrindo um amplo número de países" (GEM, 2002, p. v). Os coordenadores internacionais são o Babson College (EUA) e o London business School (Inglaterra). No Brasil os colaboradores são o SEBRAE - Nacional e o Instituto Euvaldo Lodi do Paraná (EL/PR). 


\section{trabalhonecessário}

issn: $1808-799 \mathrm{X}$

ano 7 - número 8 - 2009

viii Estas informações estão presentes no website da instituição. http://www.sebrae.com.br/br/osebrae/prioridades.asp. Acessado dia 19/11/2005.

ix Website: www.sebraesp.com.br, Formação de Jovens Empreendedores chega à rede pública de ensino. Acessado dia 04/02/2006.

x Website: www.sebraerj.com.br, SEBRAE/RJ leva lição de empreendedorismo a alunos da $1^{\mathrm{a}}$ a $8^{\mathrm{a}}$ séries. Acessado dia 04/02/2006.

${ }^{x i}$ Esta Visão Geral é um dos tópicos introdutórios da apresentação que o SEBRAE faz nas unidades escolares. Foi obtido no SEBRAE da cidade de Três Rios/RJ em 04/08/2004.

xii A noção de empreendedorismo ao longo do tempo foi desenvolvendo de forma a adquirir outras conotações. Tem-se, por exemplo, os intrapreneurs (intraempreendedores), que são os empregados que empreendem dentro do seu local de trabalho. Assim, existem compreensões de empreendedorismo (intrapreneurs) dentro da empresa. Mas no geral quando se trata do empreendedorismo, se refere fora de uma ocupação formal.

xiii Cabe assinalar que não desconhecemos os saberes formais como sendo estranhos à formação do empreendedor. Iremos nos ater ao Módulo 1 - aluno, pois à luz de nossos objetivos e análises é o que melhor expressa a perspectiva das competências que queremos demonstrar. 